\title{
THIRD PARTY CONSENT SEARCHES FOLLOWING THE SEARCH AND SURVEILLANCE ACT
}

\author{
Sam McMullan*
}

\begin{abstract}
Many New Zealanders live in shared living arrangements. The result of this is that reasonable expectations of privacy are becoming more limited. State officials may conduct a lawful search where a person consents to such a search if that person has the authority to consent. Where people live in shared living arrangements, several people may have authority to consent to a search of the same property. This article explores the extent of a third party's power to consent to property searches where more than one person has authority to consent to a search under the Search and Surveillance Act 2012. It argues that the question of reasonable expectations of privacy should not be assessed by reference to property rights. It also considers the concept of "apparent" authority which has arisen in New Zealand from the Court of Appeal's decision in R v Bradley as well as the concept of a present and objecting occupant which has arisen in the United States in the Supreme Court decision of Georgia v Randolph.
\end{abstract}

\section{INTRODUCTION}

In 2006 only 23 per cent of all households in New Zealand comprised one person. ${ }^{1}$ On average, there are 2.68 people living in each New Zealand household. ${ }^{2}$ Living in shared accommodation means that our "bubbles" of privacy are slowly being reduced. Luckily, freedom from unauthorised searches on private property has long been protected at common law. ${ }^{3}$ That freedom has also been protected more recently by s 21 of the New Zealand Bill of Rights Act 1990. But does that protection keep pace with changes in modern living arrangements?

* Sam McMullan is a staff solicitor at Meredith Connell.

1 Statistics New Zealand "Housing indicators 2008, indicator 4: one-person households" $<$ www.stats.govt.nz $>$.

2 Statistics New Zealand "Housing indicators 2008, indicator 1: occupancy rate" < www.stats.govt.nz>.

3 Geoffrey Palmer "A Bill of Rights for New Zealand: A White Paper" [1984-1985] I AJHR A6 at [10.154]; Hunter $v$ Southam Inc [1984] 2 SCR 145 at 158. 
Section 21 of the New Zealand Bill of Rights Act 1990 guarantees the right to be secure against unreasonable search or seizure, whether of the person, property, correspondence or otherwise. Section 21 is concerned with the protection of reasonable expectations of privacy. ${ }^{4}$ Therefore, as Elias CJ noted in Hamed v R, s 21 "protects 'people, not places"'. ${ }^{5}$ Once a search has been conducted in breach of an enactment (for example, s 21) any evidence obtained as a result will be deemed to be improperly obtained for the purposes of the exclusion procedure contained in s 30(5) of the Evidence Act 2006, ${ }^{6}$ and the court will have to consider whether exclusion of the evidence is a proportionate response to the impropriety. ${ }^{7}$ Exclusion will be more likely where the evidence was obtained in breach of the New Zealand Bill of Rights Act $1990 .^{8}$

Where a person has a reasonable expectation of privacy, it matters not whether he or she had a proprietary or possessory interest in the property or place: that person's privacy will be protected under s $21 .{ }^{9}$ Therefore, every person actually present at a search of private property - with the likely exception of pure trespassers on a property for unlawful purposes (such as burglars) - would have a reasonable expectation of privacy. ${ }^{10}$

If a person enters property on the basis of consent given by someone who has no authority, the person who enters will be a trespasser. ${ }^{11}$ This is the case even if the person is acting bona fide when entering the property. On the other hand, where a person gives valid consent to a search of his or her property, he or she will have granted a licence to enter property and reasonable expectations of privacy in that property will disappear. ${ }^{12}$

$4 \quad R v$ Fraser [1997] 2 NZLR 442 (CA) at 449; Hamed $v R$ [2011] NZSC 101, [2012] 2 NZLR 305 at [161] per Blanchard J (Tipping and Gault JJ concurred on that point at [209] and [281] respectively). Blanchard J went on to clarify that that does not mean that the section guarantees a reasonable expectation of privacy. McGrath J at fn 265 and Elias CJ at [10] disagreed.

$5 \quad$ Hamed $v$ R, above n 4, at [17]; Katz v United States 389 US 347 (1967) at 351.

6 Even if that search was not in breach of an enactment, it may be excluded because the evidence was obtained unfairly: Fan $v$ R [2012] NZCA 114.

7 Evidence Act 2006, s 30(2).

8 Hamed $v$, above $\mathrm{n} 4$, at [191].

$9 \quad R v$ Williams [2007] NZCA 52, [2007] 3 NZLR 207 at [63]; confirmed more recently by the Court of Appeal in Nouri v R [2012] NZCA 35 at [31]. See also David Mead "When the Police Come Knocking The Case for Review of Public Law Trespass and Consensual Entries onto Property" [2012] Crim LR 97.

$10 R v$ Williams, above $\mathrm{n} 9$, at [67].

11 See, for example Conway v George Wimpey Co (No 2) [1951] 2 KB 266 (CA).

12 A Butler and P Butler The New Zealand Bill of Rights Act: A Commentary (LexisNexis, Wellington, 2005) at [18.12.3], citing Lewis v US 385 US 206 (1966); Christopher Harker "Consent Searches and Section 21 of the New Zealand Bill of Rights Act 1990" (2011) 9 NZJPIL 137 at 150. 
At least anecdotally, most searches conducted by police are undertaken by way of consent, and so there will generally be no breach of s 21 as no "search" will result. ${ }^{13}$ Therefore, protections enacted to ensure that true consent has been obtained before such searches are undertaken, are of the utmost importance.

To be valid, consent must be voluntary, genuine ${ }^{14}$ and informed, ${ }^{15}$ and not obtained by deception or misrepresentation. ${ }^{16}$

In the context of modern living arrangements, what then of the situation when an occupier of searched premises gives consent to a State official, in particular a police officer, to search an area in which a person would otherwise have a reasonable expectation of privacy? It has been said that "searches performed on the strength of third party consent present a particularly challenging problem". ${ }^{17}$ Consider, for example, a situation familiar to many: living in a multi-bedroom flat with others. Each flatmate's bedroom is his or her exclusive domain. The kitchen, living room, bathroom and hallways are shared living quarters. When a flatmate opens the door and allows police to enter and search, is that consent limited to the bedroom of the person giving consent or does it extend to the shared living quarters and even the other flatmates' bedrooms? In other words, can one person consent to a search of another's space?

Parliament has attempted to codify consent jurisprudence into ss 91-96 of the Search and Surveillance Act 2012. ${ }^{18}$ Section 92 of that Act provides that an enforcement officer may ask a person to consent to undergo a search of any property "apparently in the control of the person". Section 94(c) provides that a search by consent will nevertheless be unlawful where that search is undertaken in reliance on consent given by a person who does not have authority to give that consent. Where a search is unlawful it will generally be unreasonable unless the illegality was minor or technical. ${ }^{19}$ Therefore, where a search is lawful under those provisions it is unlikely to be found to be unreasonable under s 21 , and thus any evidence obtained as a result is unlikely to be ruled

13 The New Zealand Police do not, however, record how searches are conducted: therefore no empirical verification of that statement could be made. See discussion in Part II below.

$14 R v$ Jefferies [1994] 1 NZLR 290 (CA).

15 Wanoa $v R$ [2010] NZCA 33 at [25]-[28]; $R$ v Rogers CA65/06, 29 May 2006 at [21].

$16 R$ v Hjelmstrom (2003) 20 CRNZ 208 (CA).

$17 R v$ Kenny (1992) 11 CR (4th) 325 (ONCA) at [19]; see also $R v$ Dornan (2008) 170 CRR (2d) 22 (ONCJ).

18 See also Law Commission Search and Surveillance Powers (NZLC R97, 2007) at [3.97]. It is expected that these provisions of the Act will come into force on or around 1 October 2012.

19 Hamed $v$ R, above $\mathrm{n}$ 4, at [174] per Blanchard J, [263] per McGrath J and [226] per Tipping J, although Tipping J prefaced that discussion by finding at [223] that the definition of search should be defined broadly with more work to be done under the unreasonableness stage; $R v$ Williams, above $\mathrm{n} 9$, at [16]; $R v$ Wojcik (1994) 11 CRNZ 463 (CA) at 465. 
inadmissible. ${ }^{20}$ Moreover, the rather vague concept of "authority" is problematic in the context of third party consent searches.

This article argues for more clarity with respect to situations in which valid consent may be given to search a third party's property. In particular it argues that reasonable expectations of privacy should be assessed by reference to what a citizen should expect in a free society and not by reference to rights to property. Part II considers the concept of an unreasonable search under s 21 of the New Zealand Bill of Rights Act 1990 and the context in which reasonable expectations of privacy apply. Part III outlines the New Zealand courts' approach to "authority" before arguing that property rights should not be the ultimate foundation on which "authority" is based. Part IV considers the concept of "apparent authority" and argues that it should not be used to enable a lawful search on the basis of consent by a person who has apparent authority to consent, but has no actual legal authority. Part V considers the issue of a person who is present at a police search but objects to the search and police conducting the search on the basis of a third party's consent. This Part argues that under s 92(c) of the Search and Surveillance Act 2012, it does not matter that a person objects to police conducting a search on the basis of actual authority given by another. A search in that situation will be lawful, since protection from an unreasonable search depends on reasonable expectations of privacy.

In determining the proper approach for New Zealand, this article draws on Canadian and United States jurisprudence with respect to the issues discussed. It is important to note the warning as to the utility of foreign jurisprudence with regard to s 21 given by the Court of Appeal in the following words: ${ }^{21}$

[Consideration of s 21] should be informed primarily by New Zealand values. The value judgments of overseas Courts may, on occasions, be helpful in a general way but ultimately New Zealand Judges must make decisions based on their own perceptions of the reasonableness of searches.

Further, while the United States' approach focuses on reasonable expectations of privacy, it is influenced by the fact that once a breach (under the United States' equivalent to s 21) occurs,

20 Although lawfulness will not be "exhaustive of unreasonable search and seizure": Hamed $v$ R, above n 4, at [51].

$21 R v$ Maihi (2002) 19 CRNZ 453 (CA) at [5]. 
evidence is automatically excluded. ${ }^{22}$ Many commentators agree that this approach has led to the United States judiciary adopting a "cynical" approach to reasonable expectations of privacy. ${ }^{23}$

\section{WHETHER A SEARCH IS IN BREACH OF S 21 OF THE NEW ZEALAND BILL OF RIGHTS ACT 1990}

\section{A What is a Search?}

Before embarking on an analysis of when a third party consent search will be lawful, it is helpful to first consider when State conduct will amount to a search.

The issue was considered by the Supreme Court in 2011 in Hamed $v R \cdot{ }^{24}$ In this case, Tipping $\mathrm{J}$ favoured a "liberal approach" to whether conduct amounts to a search. ${ }^{25}$ His Honour accordingly held that privacy issues should not be considered at that stage and that rather, they should be considered with the question of whether a search was nevertheless reasonable. ${ }^{26}$

Blanchard J, on the other hand, held that for conduct to amount to a search it must invade reasonable expectations of privacy. ${ }^{27}$ The Court of Appeal in Lorigan $v R$ recently held that while no clear majority arises from the Supreme Court's decision in Hamed, "the test ... that has the support of a majority of the Supreme Court is that proposed by Blanchard J".28

Tipping J's approach to a search does find some support in previous Court of Appeal authority such as in $R v$ Grayson and Taylor, where the Court held that a trespass onto a person's land will amount to an unreasonable search. ${ }^{29}$

22 Rakas v Illinois 439 US 128 (1978); Christopher Slobogin "Capacity to Contest a Search and Seizure: The Passing of Old Rules and Some Suggestions for New Ones" (1981) 18 Am Crim L Rev 387. Canada has followed the United States' jurisprudence: see $R v$ Edwards [1996] 1 SCR 128 and $R v$ Belnavis [1997] 3 SCR 341.

23 Paul Rishworth (ed) The New Zealand Bill of Rights (Oxford University Press, Melbourne, 2003) at 789; see also Don Stuart "The Unfortunate Dilution of Section 8 Protection: Some Teeth Remain" (1999) 25 Queen's LJ 65 at 70 and Lawn and Bernstein "Primacy to Privacy? The Supreme Court and the Privacy Threshold in Edwards" (1997) 55 U Toronto Fac L Rev 341 at 345. For example a passenger in a car has been held to have no reasonable expectation of privacy: see $R v$ Belnavis, above $\mathrm{n} 22$; Rakas $v$ Illinois, above $\mathrm{n} 22$; but see also $R v$ Williams, above $\mathrm{n} 9$, at [63].

24 Hamed $v R$, above $\mathrm{n} 4$.

25 At [222].

26 At [223].

27 At [163]. For that proposition, his Honour cited $R v$ Wise [1992] 1 SCR 527 at 533.

28 Lorigan $v$ R [2012] NZCA 264 at [22].

$29 R v$ Grayson and Taylor [1997] 1 NZLR 399 (CA) at 406; see also $R v$ Lorigan [2012] NZHC 301 at [24]; Ngan v R [2007] NZSC 105, [2008] 2 NZLR 48 at [103]. See also Chris Gallavin and Justin Wall "Hamed: s 21 BORA" [2012] NZLJ 85. 
The Court of Appeal in $R v$ Williams also said that any person with any proprietary or possessory interest in property which is searched would have an expectation of privacy which would be sufficient to have standing in a claim for a breach of s $21 .{ }^{30}$ Further, Tipping J's approach finds some support in the United States Supreme Court's 2012 decision in United States v Jones. ${ }^{31}$

United States $v$ Jones concerned the attachment of a GPS tracking device to the respondent's vehicle without a warrant. The Government obtained from that device more than 2,000 pages of data on the whereabouts of the vehicle over a four week period. The Court at first instance found that the tracking data of the respondent's vehicle, obtained while the vehicle was parked in his garage, was inadmissible. However the data relating to the tracking of the vehicle while it was being driven on public thoroughfares was admissible, since a person driving in public has no reasonable expectation of privacy.

The majority of five Supreme Court Justices found that the tracking data obtained while the respondent was driving in public was obtained by way of a search. ${ }^{32}$ The Court said that that was the case because a search occurs where there is an actionable trespass or where there is a breach of reasonable expectations of privacy. The majority continued that the Supreme Court in Katz v United States $^{33}$ had not limited the issue of what constitutes a search to breaches of reasonable expectations of privacy, but had extended it to also include reasonable expectations of privacy (along with an actionable trespass).

The minority (of four members) disagreed. The minority said that there had to be a breach of reasonable expectations of privacy for a search to have occurred. The Judges based that conclusion on their interpretation of the Supreme Court's decision in Katz which, in their opinion, did remove an actionable trespass as a foundation for a search. In short the minority held only a breach of reasonable expectations of privacy will constitute a "search" for the purposes of the Fourth Amendment. The minority ultimately agreed with the conclusion of the majority: a search had occurred. But the way in which the minority determined that a search had occurred was that officers had observed the movements of the respondent's car for such a long period of time that it breached his reasonable expectations of privacy. ${ }^{34}$

$30 R v$ Williams, above $\mathrm{n}$ 9, at [69]

31 United States $v$ Jones 565 US (2012) (forthcoming)

32 The Court was not seized of the issue as to whether the search was reasonable as that was not argued in the courts below.

33 Katz $v$ United States, above n 5.

34 This approach is supported by Blanchard $\mathrm{J}$ in Hamed $v$ R, above $\mathrm{n}$ 4, at fn 198. 
The minority's approach must, at least with respect to New Zealand, be correct. ${ }^{35}$ First, the majority of the New Zealand Supreme Court in Hamed maintained the general position that where a search is unlawful it will generally be unreasonable unless the illegality was minor or technical. ${ }^{36}$ That was in the context of a long line of authority from the Court of Appeal in New Zealand supporting that position. ${ }^{37}$ If Tipping J's approach is to be preferred, because of the current approach of the courts to the question of reasonableness, any search undertaken with the consent of a third party will be likely to be held to be unreasonable without a complete reform of the approach to the question of reasonableness. ${ }^{38}$ Further, even if the test is reformed as the onus will be on the State to prove reasonableness, there will be a strong presumption for the State to overcome in order to show that a search was reasonable.

Second, the favoured approach of the Supreme Court of Canada ${ }^{39}$ and the United States Supreme Court, ${ }^{40}$ is that concerning the role played by reasonable expectations of privacy in determining whether conduct amounts to a search.

Third, the purpose of $s 21$ is not to protect property rights but to protect privacy interests. ${ }^{41}$ Therefore, it would be an academic process to acknowledge that a search (in the broad sense) had occurred, but to never allow for a breach under s 21 unless expectations of privacy were breached. It makes for a more intuitive process to measure whether a search occurred by reference to reasonable expectations of privacy when that is what is sought to be upheld. For that reason also, Blanchard J's comments must be taken to overrule the comments of the Court of Appeal in Grayson and Taylor

35 Although, there is some Court of Appeal authority which assumes an unreasonable search where there is merely a trespass to land (due to there being no implied licence to enter). See Corless $v R$ [2011] NZCA 425 at [31]; Tararo $v$ [2010] NZCA 287, (2010) 24 CRNZ 888 affirmed in [2010] NZSC 157. Further, section 46(1)(a) of the Search and Surveillance Act 2012 now provides that a warrant is required to use any tracking device, regardless of a trespass.

36 At [174] per Blanchard J, [263] (fn 265) per McGrath J, [281] per Gault J and [226] per Tipping J, although Tipping J prefaced that discussion by finding at [223] that the definition of search should be broad with more work to be done at the unreasonableness stage.

37 Beginning with $R v$ Jefferies [1994] 1 NZLR 290 (CA). See also $R v$ Williams, above $\mathrm{n} 9$, at [16]; $R v$ Shaheed [2002] 2 NZLR 377 (CA); $R v$ Grayson and Taylor, above $\mathrm{n} 29$; and $R v$ Wojcik, above $\mathrm{n} 19$, at 465.

38 That approach is discussed below in Part III.

$39 \quad R \quad$ Wise, above n 27; Peter W Hogg Constitutional Law of Canada (5th ed, Thomson Carswell, Scarborough (Ont), 2011) at [48.7(f)].

40 Although, the Court in United States $v$ Jones, above $n$ 31, has extended the circumstances in which conduct will amount to a search to include where an actionable trespass was committed.

41 Hamed $v$ R, above n 4, at [10]; Katz v United States, above n 5, at 350; United States $v$ Jones, above n 31, per the minority. 
and Williams. ${ }^{42}$ That is because merely having an interest in property which is the subject of a search will not be sufficient. It must be shown that the person whose property is being searched has reasonable expectations of privacy with respect to that property.

\section{B Reasonable Expectations of Privacy}

There is no guaranteed right to privacy in the New Zealand Bill of Rights Act. ${ }^{43}$ However, expectations of privacy are recognised both in search and surveillance cases ${ }^{44}$ and by the tort of privacy. ${ }^{45}$

The courts' focus in determining reasonable expectations of privacy has, at least in the search and surveillance cases, generally been on the interest of the person (who is subject to the search) in the property, ${ }^{46}$ as well as on whether he or she has assumed any risk in sharing his or her interest in the property with another. ${ }^{47}$ Persons who share an interest in property do so over the whole of that property. ${ }^{48}$ Therefore, the "assumption of risk" doctrine can be justified on property rights grounds because where more than one person has exclusive possession of a particular dwelling house, there is a risk that the privacy of some of them will be intruded upon. ${ }^{49}$

The assumption of risk doctrine can also be justified on privacy grounds to extend it beyond those who hold an interest in property. In the context of the tort of privacy, facts in respect of which there is a reasonable expectation of privacy are said to be private facts which "may be known to some people, but not to the world at large". ${ }^{50}$ For example, sharing in a flatting situation may extend to entertaining (non-occupier) friends in a shared lounge. In those circumstances, there will no longer be any expectation of privacy in respect of that area.

$42 \quad R v$ Grayson and Taylor, above $\mathrm{n} 29 ; R v$ Williams, above $\mathrm{n} 9$.

43 Lange v Atkinson [2000] 3 NZLR 385 (CA) at 396; Hosking v Runting [2005] 1 NZLR 1 (CA) at [77].

44 Hamed $v$ R, above $\mathrm{n} 4$.

45 Hosking v Runting, above n 43; Rogers v Television New Zealand Ltd [2007] NZSC 91, [2008] 2 NZLR 277.

46 Attorney-General v Hewitt [2000] 2 NZLR 110 (HC) at [26]-[27]; R v Pluss CA485/97, 25 February 1998 at 4 .

47 Aubrey H Brown "Georgia v Randolph, the Red-Headed Stepchild of an Ugly Family: Why Third-Party Consent Search Doctrine is an Unfortunate Fourth Amendment Development That Should be Restrained" (2009) 18 Wm \& Mary Bill Rts J 471 at 490.

48 GW Hinde and others Land Law in New Zealand (Butterworths, Wellington, 1997) at [9.035].

49 See the approach of the Court in Nouri $v$ R, above $n$ 9, at [31].

50 Hosking $v$ Runting, above n 43, at [119]; Rogers $v$ Television New Zealand Ltd, above n 45, at [98] and [100]. 
Too often the courts in New Zealand have based their approach to reasonable expectations of privacy on property rights. A formal proprietary approach renders reasonable expectations of privacy too limited. As Blanchard J noted in Hamed, the test for reasonable expectations of privacy is already limited. His Honour said that for an expectation of privacy to be reasonable, the person complaining of a breach of s 21 ought to have subjectively held the expectation and that the expectation must be one that society is prepared to recognise as reasonable. ${ }^{51}$

As for the subjective element, Binnie $\mathrm{J}$ in the Supreme Court of Canada said in $R v$ Tessling: ${ }^{52}$

The subjective expectation of privacy is important but its absence should not be used too quickly to undermine the protection afforded by s 8 to the values of a free and democratic society. In an age of expanding means for snooping readily available on the retail market, ordinary people may come to fear (with or without justification) that their telephones are wiretapped or their private correspondence is being read. ... Suggestions that a diminished subjective expectation of privacy should automatically result in a lowering of constitutional protection should therefore be opposed. ... Expectation of privacy is a normative rather than a descriptive standard.

Those comments should also be seen in light of the New Zealand Parliament's requirement under the Search and Surveillance Act 2012 that an officer who requests a consent search must advise the subject of the search that he or she may refuse to consent, ${ }^{53}$ thus requiring that the subject of the search be fully informed. This suggests a movement toward enhancing what Elias CJ recorded in Hamed as the proposition that the right protected by s 21 is "the right of the individual to determine for himself when, how, and to what extent he will release personal information about himself". ${ }^{54}$ In those circumstances, merely because a subject of a police search did not know that privacy could be expected in that situation should not necessarily mean that protection will not extend under s 21 where any other reasonable person would have expected privacy in those circumstances. That is because a person should be informed of what he or she should expect before his or her interest in privacy is infringed. Further, the test is not "could this criminal reasonably expect privacy in this situation". ${ }^{55}$ As noted by Binnie J, subjective expectations must not be used to diminish expectations to privacy.

51 Hamed $v R$, above n 4, at [163]; $R \vee$ Grayson and Taylor, above $\mathrm{n} 29$, at 407.

$52 R v$ Tessling 2004 SCC 67, [2004] 3 SCR 432 at [42].

53 Section 93(c).

54 At [11], citing $R v$ Duarte [1990] 1 SCR 30 at 46.

55 See, for example, the Court of Appeal's approach in $R v$ Savelio CA234/96, 5 August 2005 at [46] which was later rejected by the Court in $R v$ Williams, above $n$ 9, at [63]; see also Hart Schwartz "The Short Happy Life and Tragic Death of the New Zealand Bill of Rights Act" [1998] NZ L Rev 259 at 292; Richard Mahoney "Evidence" [2006] NZ L Rev 105 at 115. 
As for the objective element, it has been said that the judiciary is poorly suited to determining rules of social convention. ${ }^{56}$ So, while some value judgement is necessary, ${ }^{57}$ judges should not be too willing to displace the arrangement in a particular living situation with their own view as to how people ought to live. That is the only way in which true recognition can be given to reasonable expectations of privacy.

A person's reasonable expectation of privacy should therefore be assessed by what a citizen should expect in a free society. Vague distinctions of relationships between people should not be used to distinguish reasonable expectations of privacy. ${ }^{58}$ Where a focus is placed too heavily on property rights the question moves away from what one objectively, reasonably, can expect his or her veil of privacy to extend to. If property rights were the touchstone, many of those requiring the greatest level of protection would lose out as those people often do not have rights to property which they can rely on.

Therefore, the question should be to what extent a person has subjective common authority over an area - not actual authority in a legal sense. A focus purely on expectations of privacy and not on property rights as a form of establishing that expectation, makes the inquiry more objectively reflect how society operates.

\section{AUTHORITY TO CONSENT TO A THIRD PARTY CONSENT SEARCH}

There are few cases in New Zealand where the courts have considered the issue of actual authority to consent to a search. Nevertheless, despite the statement of the Court in $R v$ Williams, the courts have consistently assessed authority to consent on the basis of property rights. ${ }^{59}$ The decisions of the courts in $R v$ Savelio $^{60}$ and $R v$ Harris $^{61}$ illustrate that approach.

56 Stephanie Godfrey and Kay Levine "Much Ado About Randolph: The Supreme Court Revisits Third Party Consent" (2007) 42 Tulsa L Rev 735 at fn 137; "Leading Cases 4: Georgia v Randolph" (2006) 120 Harv L $\operatorname{Rev} 125$ at 170.

$57 R v$ Jefferies [1994] 1 NZLR 290 (CA) at 299.

58 The Court in $R v$ Williams, above $\mathrm{n} 9$, at [67] said that it was persuaded by the dissent in $R v$ Belnavis, above $\mathrm{n} 22$ to reject its approach in $R v$ Edwards, above n 22. The Court summarised its understanding of that dissent at [56].

59 See $R$ v Pluss, above n 46; Attorney-General v Hewitt, above n 46; Cunningham v Police (1997) 4 HRNZ 240 (HC); Baker v Police [1997] 2 NZLR 467 (HC); Moses v Police HC Auckland CRI-2006-404-250, 23 November 2006; $R$ v Savelio, above n 55; $R$ v Su HC Auckland CRI-2006-092-16424, 10 July 2008; $R v$ Harris HC Palmerston North CRI-2006-054-1008, 21 November 2006.

$60 R v$ Savelio, above $\mathrm{n} 55$. But see $R v$ Williams, above $\mathrm{n} 9$, at [63]. See also Mahoney, above $\mathrm{n} 55$.

$61 \quad R v$ Harris, above n 59. 
In Savelio the appellant was suspected of committing a burglary. A police officer had seen him enter his father's house. The house was searched pursuant to a search warrant and incriminating effects were found. The Court held that the appellant had no standing to argue a breach of s 21 as he had no reasonable expectation of privacy in the property. That finding was made despite evidence that the appellant used the garage to "bunk up". However, the Court said that his licence to use the garage did not include permission to use it as a base for committing serious crimes. ${ }^{62}$

In Harris, Miller $\mathrm{J}$ considered the legality of a police search conducted on a motel room. Here the guests had stayed on after the 10 am required checkout time. His Honour's analysis turned on the guests' licence to remain in the hotel. Miller $\mathrm{J}$ said that a licensor who enters property over which an exclusive licence has been granted has breached his contractual obligations but is not a trespasser. Accordingly, his Honour concluded that the contract had expired and the motelier was contractually entitled to enter the room. The Judge further commented (relying on the Court of Appeal's decision in $R v$ Bradley) that the motelier had ostensible authority in any event, as he had advised police that the guests had stayed past their checkout time. ${ }^{63}$ Therefore the police had authority to enter.

Given the limited range of New Zealand authority, it is helpful to look to the approaches of the courts in the United States and Canada.

\section{A United States}

In the United States, whether consent for a third party search was validly given is based on two elements: joint access and control and an assumption of risk. Where a person allows another person joint access over a particular area, that person assumes the risk that the other will allow it to be searched. The courts have specified that that inquiry is not based on property law. ${ }^{64}$ The Supreme Court's primary authority for that proposition is its decision in United States v Matlock. ${ }^{65}$

In Matlock the police arrested the appellant and then asked another resident of the home whether they could search it. ${ }^{66}$ That resident consented. A large amount of cash was found in the closet of a bedroom which the pair jointly occupied. The Court said that the consent was valid. ${ }^{67}$ It found that the resident had actual authority to consent, saying, "the consent of one who possesses common

62 At [46].

63 At [29]; $R v$ Bradley (1997) 15 CRNZ 363 (CA).

64 Jason E Zakai (2007) 73 Brook L Rev 421 at 429; although see the approach of the Supreme Court in United States v Jones, above n 31.

65 United States v Matlock 415 US 164 (1974).

66 At 166 .

67 At 171 . 
authority over premises or effects is valid as against the absent, non-consenting person with whom that authority is shared." 68

The Court said further that "common authority" is established by: 69

... joint access or control for most purposes, so that it is reasonable to recognize that any of the coinhabitants has the right to permit the inspection in his own right and that the others have assumed the risk that one of their number might permit the common area to be searched.

\section{B Canada}

Canada's analogue to New Zealand's Bill of Rights Act s 21, is s 8 of the Canadian Charter of Rights and Freedoms (the Charter). A helpful illustration of the approach to reasonable expectations of privacy, without reliance on property rights, is the Ontario Court of Appeal's decision in $R v$ Cole.$^{70}$ In $R v$ Cole the appellant was a teacher who had been provided a laptop by his school. During the course of regular monitoring of the school's network, a technician found a hidden folder on the teacher's hard drive. In that folder the technician found pornographic images which he believed to be of students. The technician took a screen shot of the images and alerted the principal who, in turn, alerted the police. The police then seized the appellant's laptop and the principal passed on the screen shot of the images. The Ontario Court of Appeal considered that the appellant had a reasonable expectation of privacy in both the hard drive of the laptop and the personal information that it contained. The Court considered the fact that the laptop was able to be used for personal use, and that there was no clear privacy policy around its use at the school, to be factors weighing in favour of that conclusion. The Court said, however, that the appellant knew that the school technician had a limited right of access to the hard drive as part of his duties to maintain the stability and security of the network. ${ }^{71}$ That operated to modify the appellant's reasonable expectation of privacy to that limited scope. Accordingly, the technician did not breach s 8 of the Charter as his search was conducted for that limited purpose. ${ }^{72}$

The Court further held that because the appellant and teachers at the school were expressly permitted to store personal information on their work computers, the school Board did not have the authority to consent to a search of the work laptop. ${ }^{73}$ As there were no exigent circumstances, the

68 At 170

69 At fn 7.

$70 R v$ Cole 2011 ONCA 218, (2011) 269 CCC (3d) 402.

71 At [47].

72 At [58].

73 At [73]. 
search by the police was found to be unreasonable ${ }^{74}$ and the evidence was to be excluded. ${ }^{75}$ However, the screen shot contained photographs which were obtained by the technician "in plain view, while engaged in permissible access". ${ }^{76}$ Therefore, the appellant had no privacy interest in respect of them. ${ }^{77}$

The Court of Appeal for Ontario's decision in $R v$ Kenny ${ }^{78}$ provides an interesting contrast to the approach of Miller $\mathrm{J}$ in Harris. ${ }^{79}$ In Kenny, the Court found that a hotelier could not consent to a police search of a guest's rented room. The guests of the room were away and they left a "do not disturb" sign on the door. Guests were aware that cleaning staff would enter their rooms at least daily. In the respondent's case a member of the cleaning staff entered their room in order to clean it. She noticed that one of the pillows was missing from the bed and found it on the floor. Inside the pillow case she found money (police counted over CAD 6,000). She alerted the hotel manager who also entered the room. He noticed the money and also found a brown waxy brick (police determined that this was cannabis resin). Police were then called and further searched the room.

The issue of third party consent searches has come under more detailed scrutiny by the Supreme Court of Canada in two decisions: $R v$ Edwards ${ }^{80}$ and $R v$ Tessling. ${ }^{81}$

In $R v$ Edwards (the approach which the majority the New Zealand Court of Appeal rejected in $R v$ Williams $^{82}$ ), the Supreme Court of Canada considered that a suspect who left drugs in his girlfriend's apartment had no reasonable expectation of privacy in circumstances where the girlfriend consented to the police search of the apartment. The Court clarified that the protection under s 8 of the Charter is a personal right. Therefore an accused must establish that his personal rights to privacy have been violated. ${ }^{83}$ The Supreme Court said that a reasonable expectation of

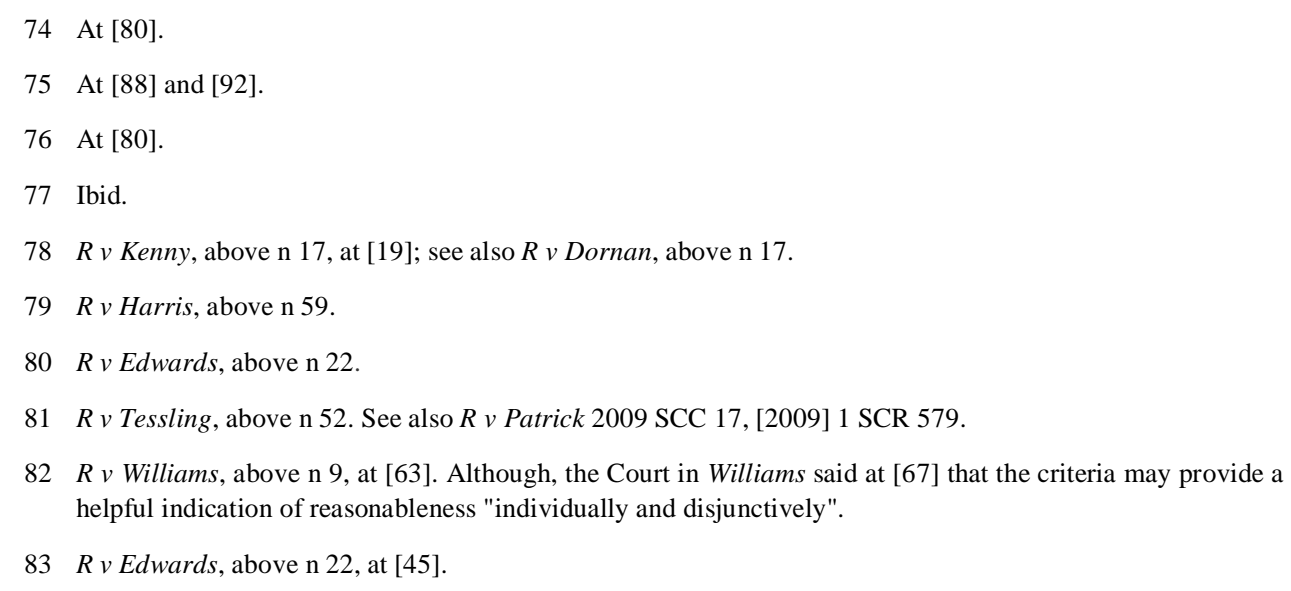


privacy is to be determined on the basis of the totality of the circumstances and proceeded to provide seven non-exhaustive factors to consider. Those were: ${ }^{84}$

(1) presence at the time of the search;

(2) possession or control of the property or place searched;

(3) ownership of the property or place;

(4) historical use of the property or item;

(5) the ability to regulate access, including the right to admit or exclude others from the place;

(6) the existence of a subjective expectation of privacy; and

(7) the objective reasonableness of the expectation.

In Edwards, the appellant had no expectation of privacy in his girlfriend's apartment. ${ }^{85}$ That finding was influenced by the fact that Edwards' girlfriend said that he was "just a visitor" who stayed over occasionally. Further, he did not contribute to the apartment's rent or household expenses. Finally, although Edwards had keys to the apartment he lacked the authority to regulate access to the apartment. So while his girlfriend could admit or exclude anyone of her choosing, Edwards could not. ${ }^{86}$

The Supreme Court has since provided a further analytical framework for assessing the totality of the circumstances. The Court in Tessling ${ }^{87}$ said that in determining the reasonableness of the privacy expectation, the framework is a useful analytical tool to determine the nature of the privacy interest. The analytical framework suggested involves consideration of the nature or subject-matter of the evidence gathered; whether the applicant had a direct interest in that subject-matter; whether the applicant had a subjective expectation of privacy in the subject-matter; the nature of the privacy interest; and whether that expectation of privacy was objectively reasonable. The Court then set out seven factors to consider in determining whether the expectation was objectively reasonable. They were: 88

(1) the place where the alleged "search" occurred;

(2) whether the subject-matter was in public view;

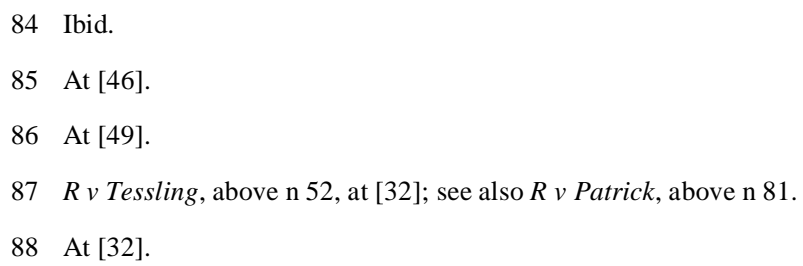


(3) whether the subject-matter had been abandoned;

(4) whether the information was already in the hands of third parties; if so, was it subject to an obligation of confidentiality?

(5) whether the police technique was intrusive in relation to the privacy interest;

(6) whether the use of surveillance technology was itself objectively unreasonable; and

(7) whether the Forward Looking Infrared heat profile ${ }^{89}$ exposed any intimate details of the respondent's lifestyle, or information of a biographical nature.

\section{Actual Authority}

The question of actual authority should therefore be considered on the basis of the principles discussed above with regard to reasonable expectations of privacy and not, as in the decisions of the New Zealand courts, by reliance on property rights. The question is whether there is sufficient common authority over an area such that the subject of the search has no reasonable expectation of privacy with respect to the area. Where factors such as proprietary interest and the other factors outlined in Tessling and Edwards ought to be considered is, as the Court in Williams suggested, through the balancing process in s 30 of the Evidence Act 2006. ${ }^{90}$ Part of the s 30 analysis requires an assessment of the strength of a person's relationship with the subject property, rather than their legal relationship to the property. ${ }^{91}$ The factors outlined by those two cases may also be of assistance in determining whether a search (one which breached reasonable expectations of privacy) was unreasonable. That is because in deciding whether a search was unreasonable, three criteria must be applied: the nature of the place of the search; the degree of the intrusion; and the purpose of the search. ${ }^{92}$

In applying that approach to "actual authority" take, for example, a situation such as that in $R v$ Savelio, where a young adult lives with his or her parents. ${ }^{93}$ Add to it that the young adult has property in a part of the house which is used exclusively by that young adult. Consider also that the parents would not enter that area without first asking the young adult. While it cannot be disputed that the parents could, legally, enter that area without the young adult's consent (the property being exclusively theirs) and that actual use is not a requirement for reducing reasonable expectations of

89 The issue in $R v$ Tessling, above $\mathrm{n}$ 52, concerned the lawfulness of a search by way of a thermal imaging camera.

$90 R v$ Williams, above $\mathrm{n} 9$, at [74].

91 Section 30(3) provides eight factors to consider "among others" in conducting the balancing process.

92 Hamed $v$ R, above $\mathrm{n}$ 4, at [172] per Blanchard $\mathrm{J}$.

93 The Court in $R v$ Williams, above $\mathrm{n} 9$, said at [63] that its decision in $R v$ Savelio, above $\mathrm{n} 55$, was incorrect. 
privacy, ${ }^{94}$ for the parent to enter would not, based on the state of the relationship, breach that young adult's reasonable expectation of privacy. There must be some element of foreseeability in the intrusion into the person's space. ${ }^{95}$ As the Ontario Court of Appeal held in $R v$ Cole $^{96}$ (where a school permitted teachers to store personal information on a work computer), the school could not search that material other than for remote maintenance. The same situation must exist with regard to a house in which a young adult is led to believe that he or she can keep personal material safe in his or her bedroom.

Such a situation can be contrasted with that where a family enjoys an "open door" policy whereby each family member is free to enter one another's rooms at will - for example to pick up or return laundry - at reasonable hours of the day.

Transform those two situations into shared flatting situations. In one house the occupants may always keep their bedroom doors closed and never enter one another's rooms. That can be contrasted with the situation where flatmates live much more like a family and it would be acceptable for someone to walk into another person's room to borrow a computer.

While that contrasts the living situation as between occupants, that does not mean that it would be acceptable for a stranger (such as a police officer) to enter. For example, it may not be acceptable for a stranger to accompany the family member returning laundry or the flatmate borrowing a computer. In those circumstances, the subtleties of a relationship must be considered in order to determine whether that person had actual authority to consent. It should be remembered that in the context of the tort of privacy, merely because private facts are known to some does not mean that there is no longer any expectation of privacy with respect to them. It is a question of degree.

Some decisions have sought to simplify the inquiry of authority by finding that some relationships raise a presumption of control such that authority can be presumed. ${ }^{97}$ However, to allow the creation of presumptions would lead to the subject of searches being placed in the highly difficult situation of having to adduce evidence to rebut that presumption. The protection sought is protection for people's expectations of privacy. Given that privacy is so easily removed but so hard to uphold, providing the highest barrier to ensure its protection is vital.

94 People v Catlin 26 Cal 4th 81 (Cal 2001) at 163; US v Sealey 830 F 2d 1028 (9th Cir 1987) at 1031.

$95 R v$ Su HC Auckland CRI-2006-092-16424, 10 July 2008 at [37] and [80]; US v Jeffers 342 US 48 (1951) at 51

$96 \quad R v$ Cole, above $\mathrm{n} 70$

97 See, for example US v Rith 164 F 3d 1323 (10th Cir 1999) at 1331. 


\section{APPARENT AUTHORITY}

In $R v$ Bradley ${ }^{98}$ the Court of Appeal held that an occupier may consent to a search where that occupier's conduct, along with the circumstances, reasonably led the police to conclude that the occupier had authority to give consent. ${ }^{99}$ That conclusion was based on the premise that if the occupier had no authority to consent she would not have. ${ }^{100}$

In contrast to the Court of Appeal's approach in Bradley, s 94 of the Search and Surveillance Act 2012 appears to require a more limited view of authority. Section 94(c) provides that a search by consent is unlawful if the search is undertaken in reliance on consent given by a person who does not have authority to give that consent.

The Law Commission said in its report on what became the Search and Surveillance Bill:101

$\ldots$ if an enforcement officer is acting on a reasonable belief that the person has actual authority to consent when that is not in fact the case, that is very unlikely to be subsequently held to be unreasonable.

In $R v$ Kenny, Arbour JA said: ${ }^{102}$

The notion of "apparent authority" refers, in my view, to a reasonable mistake of fact with respect to the identity of the person giving the consent and not to a misconception, reasonable or not, as to whether the management of a hotel has a sufficient possessory or other interest in a room rented to a guest to be empowered to authorize police entry in the absence and without the consent of the guest. Such misconception, if it exists, rests on a mistake of law and its significance is better assessed, in Canadian law, under [the exclusion of evidence provision in] s. 24(2) of the Charter.

Arbour JA's statement is equally apt in light of s 94 of the Search and Surveillance Act. If police searched premises on the basis of a consent from someone whom officers believed had authority to consent to a search, when in fact he or she did not, that does not mean that the search was legal, although the search may not necessarily be held to be unreasonable. That finding of legality follows from the premise that s 21 of the New Zealand Bill of Rights Act exists to protect individuals'

$98 \quad R v$ Bradley, above n 63.

99 At 369; see also Manzone v Police HC Wellington AP293/99, 6 December 1999 at [14]-[15]; see also $R v$ Harris, above n 59.

100 At 369. Thomas $\mathrm{J}$ said "If [the person consenting] in fact had no authority or status she could have been expected to avoid a positive answer".

101 Law Commission, above n 18, at [3.98], and see the comments at [3.92] also.

$102 R v$ Kenny, above $\mathrm{n} \mathrm{17}$, at [22] and more recently affirmed by the Ontario Court of Appeal in $R v$ Cole, above $n 70$. 
privacy rights. People do not expect that others will intrude based on a person's misrepresentation that he or she holds authority over property which that person does not, in fact, have.

Limitation of the apparent authority doctrine to mistakes of fact also finds support in dicta of the United States Supreme Court. ${ }^{103}$ In Illinois $v$ Rodriguez ${ }^{104}$ the appellant's partner had been beaten by the appellant, but she did not reside at his address. She led police to the appellant's apartment, where she provided them with a key and referred to the apartment as "ours". ${ }^{105}$ The police entered the apartment, on the basis of that consent, and saw drugs in plain view. The appellant was asleep in his bedroom and was duly arrested. The Supreme Court recognised that common authority is not always easily ascertainable. The Court considered that where a police officer reasonably believes that the third party possesses the authority to permit a search, the search will be valid. ${ }^{106}$ In a persuasive dissent, Marshall $\mathrm{J}$ said that the constitutional justification for Matlock was avoided by the majority in Rodriguez as the assumption of risk rule rested on the idea that a person had given up his or her expectation of privacy when he shared access with a co-tenant. ${ }^{107}$ That constitutional footing is avoided when police operate on the basis of a mistaken belief, as there is no assumption of risk.

That authority has more recently been extended in at least one State to allow police to "assume, without further inquiry, that a person who answers the door in response to their knock has the authority to let them enter". 108

The Search and Surveillance Act's limitation to a mistake of law is likely to mean that the New Zealand courts would not extend the doctrine to the same extent as the United States courts have. Further, the effect of protecting against a mistake of law is likely to mean that questions will need to be asked by an officer in order to ensure that the person does, in fact, have authority. State officials must not, as Thomas J suggested in $R v$ Bradley, ${ }^{109}$ assume that if the occupier had no authority to consent, he or she would automatically not have consented. ${ }^{110}$ Indeed, there is a general acceptance

103 Illinois v Rodriguez 497 US 177 (1990) at 186; Brinegar v United States 338 US 160 (1949) at 176.

104 Illinois v Rodriguez, above n 103.

105 At 179.

106 At 188-189.

107 At 194

108 People v Ledesma 39 Cal 4th 641 (Cal 2006) at 705.

$109 R v$ Bradley, above $\mathrm{n}$ 63, at 369 where Thomas $\mathrm{J}$ said "If [the consentor] in fact had no authority or status she could have been expected to avoid a positive answer".

110 See also the comments by Russell M Gold "Is this Your Bedroom? Reconsidering Third-Party Consent Searches Under Modern Living Arrangements" (2008) 76 Geo Wash L Rev 375 at 389; Tammy Campbell "Illinois v Rodriguez: Should Apparent Authority Validate Third-Party Consent Searches?" (1992) 63 U Colo L Rev 481 at 498-499. 
that police will act reasonably in endeavours such as conducting searches based on consent. ${ }^{111}$ Surely it is reasonable to undertake enquiries to determine whether a person does, in fact, have authority. The New Zealand approach is therefore aligned with that of the United Kingdom where, under the Police and Criminal Evidence Act 1984 (UK) Codes of Practice, an officer must make sufficient enquiries to ensure that a person has authority. ${ }^{112}$ It must always be remembered that the balancing test in s 30(2) of the Evidence Act 2006 requires consideration of any bad faith on the part of the State official in obtaining evidence. Therefore, where a search was conducted illegally under $\mathrm{s}$ 94(c) of the Search and Surveillance Act, any evidence obtained from that search will not necessarily be excluded.

\section{PRESENT AND OBJECTING}

This issue concerns a person whose property is the subject of a search and who is present at the time of the search but objects to the search in the face of another person's valid consent. The issue was considered by the United States Supreme Court in the 2006 case of Georgia v Randolph. ${ }^{113}$ In Randolph the Supreme Court held that police could not reasonably rely on a wife's consent to a warrantless search of her home when her co-tenant husband was physically present and objecting to the police intrusion. The Court based its decision on "widely shared social expectations" regarding the marital relationship and the dynamics of co-occupancy. ${ }^{114}$ Under the social expectations standard, the Court said that it was unreasonable for the police to search the home because no regular house guest would feel comfortable entering the home when one tenant welcomed the guest and the other asked the guest to leave. ${ }^{115}$ The Court said that since the wife had no authority under the law and social practice did not allow her to override her husband's views, the effect of the husband's objection was to render the search analogous to there having been no consent at all. ${ }^{116}$

The Court went on to say that absent "some recognized hierarchy, [like a household of] parent and child there is no societal or legal understanding of superior and inferior", and each co-tenant "has the right to use and enjoy the entire property as if he or she were the sole owner, limited only

111 See Illinois v Rodriguez, above n 103, at 185-186.

112 Police and Criminal Evidence Act 1984 (UK), Code B, 5.1. That Code is a "soft-law" recognition and it is not clear whether the Code applies to entries to property: Mead, above n 9, at 107. Therefore, it only requires police to inform a person of the right to refuse when they are already on that person's property and wish to conduct a search by consent.

113 Georgia v Randolph 547 US 103 (2006). The issue was also, tangentially, discussed by Simon France J in Moses $v$ Police, above n 59, at [15].

114 At 111 .

115 At $113-114$.

116 At 114. 
by the same right in the other" co-tenants. ${ }^{117}$ Therefore, no one occupant should have a superior property right over another. ${ }^{118}$

Roberts CJ, whose judgment is said to have a more sensible reading of precedent, ${ }^{119}$ was not persuaded by the social expectations standard. His Honour said that the proper inquiry under Katz $^{120}$ was whether there existed an expectation of privacy. His Honour continued and said that there are social situations where a guest would stay despite the contradiction in consent by the cotenant parties. ${ }^{121}$ Further, given the complexities of human relationships and social expectations, the standard mooted by the majority will be difficult to apply. ${ }^{122}$ Third, his Honour said that the Constitution protects not only social expectations but also privacy. Therefore, once privacy has been shared an expectation of solitude becomes less reasonable.

In summary, the two competing ideas from Randolph are that the risk assumed by an absent occupant of shared premises does not exist when he or she is present, as opposed to the view that by sharing property with another, a person invites a dilution of privacy.

The result of the majority's decision means that Matlock ${ }^{123}$ applies only to a co-tenant and not a house guest. ${ }^{124}$ That begs the question: why should a house guest have more rights of privacy than a spouse?

The application of the Randolph doctrine has also led to some differing results. In United States $v$ Groves the appellant declined consent to police but when the police returned a couple of weeks later to find that the appellant was not present they searched his home on the authority of his girlfriend's consent. ${ }^{125}$ The Seventh Circuit of appeals upheld that search. In United States $v$ Henderson the appellant refused to consent to entry so the police arrested him. ${ }^{126}$ Later his wife consented to a search and that search was also upheld. Further, the Third Circuit held - likening

\section{Ibid.}

118 Ibid.

119 See "Leading Cases 4: Georgia v Randolph", above n 56, at 164.

120 Katz $v$ United States, above n 5.

121 At 129-130. Contrast "Leading Cases 4: Georgia v Randolph", above n 56, at 168, where the author notes that the Supreme Court has determined Fourth Amendment cases on the basis of social expectations of privacy for over 40 years.

122 Georgia v Randolph, above n 113, at 130.

123 United States v Matlock, above n 65.

124 Georgia v Randolph, above n 113, at 113.

125 United States v Groves 530 F 3d 506 (7th Cir 2008).

126 United States v Henderson 536 F 3d 777 (7th Cir 2008). 
personal property to a secret - that the doctrine in Randolph does not apply to personal property. The Court said: "... once an owner shares [personal property] ... he assumes the risk that his confidante will share it with the police". ${ }^{127}$ That dicta was confirmed by the same Court in United States $v$ Stabile. ${ }^{128}$

Given the New Zealand judiciary's reliance on property rights as the basis for determining whether a search is unreasonable, it is likely that the approach of the majority of the Supreme Court in Randolph will be followed. Indeed, the general lack of inclination to ignore property rights and focus instead on privacy is something with which courts in the common law world have struggled. However, the Randolph approach cannot be right. The basis of third party consent searches is that people expect that there is a likelihood, a risk even, that someone may rifle through their possessions.

The minority's approach means that a person who, for example, gives an intimate partner a key to his or her apartment, accepts a risk that their partner may validly consent to a police search of that person's apartment. ${ }^{129}$ That risk will occur where the partner is allowed access to all rooms within that apartment and is allowed to bring others into the apartment, perhaps friends for a drink before going to a show. Such an approach is entirely consistent with a diminishing reasonable expectation of privacy with respect to the owner's apartment vis-à-vis his or her partner.

Sharing a home with others does not necessarily mean that the co-occupants expect intrusions by police officers, ${ }^{130}$ and there are social situations where a guest would stay despite the contradiction in consent by the co-tenant parties. ${ }^{131}$ Further, it must be accepted that it is an odd extension to allow waiver by one person of another's rights, absent an express agency relationship, ${ }^{132}$ and so a presently objecting person will not be able to protect his or her own privacy once consent to search is given by another. ${ }^{133}$ The only way to uphold reasonable expectations of privacy is to prefer the approach of Roberts $\mathrm{CJ}$ in Randolph, for only that approach recognises that expectations of privacy exist independently of property rights. That is primarily because once the

127 United States v King 604 F 3d 125 (3d Cir 2010) at 136.

128 United States v Stabile 633 F 3d 219 (3d Cir 2011) at 233.

129 This provides a similar example to the facts of $R v$ Edwards, above $\mathrm{n} 22$, and $R v$ Belnavis, above $\mathrm{n} 22$.

130 Sharon E Abrams "Third-Party Consent Searches, the Supreme Court, and the Fourth Amendment" (1984) 73 The Journal of Criminal Law and Criminology 963 at 985.

131 Georgia v Randolph, above n 113, at 129-130. Contrast "Leading Cases 4: Georgia v Randolph", above n 56, at 168 where the author notes that the Supreme Court has determined Fourth Amendment cases on the basis of social expectations of privacy for over 40 years.

132 Abrams, above n 130, at 989.

133 C Dan Black "Georgia v Randolph: A Murky Refinement of the Fourth Amendment Third-Party Consent Doctrine" (2007) 42 Gonz L Rev 321 at 333; Georgia v Randolph, above n 113, at 114. 
person has forgone any privacy right with respect to that particular area (or apartment), expectations of privacy have disappeared. ${ }^{134}$ An odd situation would then ensue if that person could be said to regain his or her privacy at the 11th hour. Further, to hold otherwise would be tantamount to protecting a person's right to be free from unreasonable searches while they are home but not while they are away. ${ }^{135}$ If that were the case, protection from a search would hinge on the luck of being present when the police arrive.

As Roberts CJ said in Randolph, ${ }^{136}$ while it may be against social convention for a person to enter in the face of another person's opposition, in that it would not be good manners, the law does not exist to protect manners. However, if the question was "would the objector have allowed the guest into the property", that would limit authority to consent to a power similar to an agency right. In the end, that question would almost always be answered in the negative through the benefit of hindsight.

Care must be taken in order to ensure that consideration of whether authority is held is undertaken with recourse to the particular living situation of the occupants of a house. But that does not mean that some hierarchy of consent should then be considered in determining whether another person can override one person's consent by refusing entry to a third party. Once authority to consent is established, the person with that authority may share the space which he or she has access to.

Ultimately, this debate falls on the fact that s 21 protects privacy. Where a person has already decreased his or her reasonable expectations of privacy by sharing their living space, that person also risks a bad-mannered person sharing it with another. Even though information may originate with a particular person, this does not mean that he or she will always be able to prevent the further dissemination of that information. Entry into property cannot be seen any differently. At its most basic, what people seek to protect is information - particularly information which links them to some criminal activity. To ensure that information stays private, it must not be shared with anyone else. That can be done by keeping it in a place (such as a bedroom) into which entry is not shared with anyone else, and in respect of which there is no reduced expectation of privacy.

\section{CONCLUSION}

The Search and Surveillance Act 2012 codifies the varying approaches to consent and third party consent searches which have been undertaken by the common law. The foundation for allowing those searches is still reasonable expectations of privacy (or reduced reasonable

134 See also the approach of the Search and Surveillance Act 2012 to intercepted communications, at s 47(1)(b) of that Act.

135 Abrams, above n 130, at 977.

136 At 131. 
expectations of privacy). Property rights cannot be used as the touchstone. That means that authority to consent to a search must be determined and established on the basis of reasonable expectations of privacy. While that may result in persons who do not have a right to property (beyond a mere licence) having an ability to consent - or refuse to consent - to a search, that is the only way in which a person's rights as guaranteed by s 21 of the New Zealand Bill of Rights Act 1990 can be protected.

In order to uphold those rights, a police officer cannot be allowed to act on the consent of a person without first ensuring that actual authority is held. The doctrine of apparent authority can only excuse a mistake of fact and not a mistake of law that the person is someone who actually has authority.

Finally, the issue of present and objecting individuals can prevent a search which is sought to be undertaken in light of another occupant's consent. Notwithstanding the approach of the majority of the Supreme Court in Randolph, that inquiry must also be undertaken on the basis of reasonable expectations of privacy. To find otherwise would maintain the current lip service paid to reasonable expectations of privacy.

Determining whether State officials can act on the authority of an occupant will depend on an assessment of reasonable expectations of privacy. Where it has been assessed that, on the basis of the relationship between the individuals concerned, the person who consents would not ordinarily be granted unfettered access to a space within the house, a search conducted on the basis of that person's consent will be unlawful. However, where authority to consent is held, that person will be able to consent to a search for all purposes notwithstanding the views of another person who might also hold authority. 
